Perhaps that would be as far as we ought to go at present, but I would very much like to see, in addition to the above, a requirement that all graduating after 1903, applying for recognition from the Association or its auxiliary bodies, be required to produce evidence that they have had a preliminary education equal to that obtained in a first-grade high school course, as is now required by law in the states of New York, New Hampshire and Ohio (Amendment to Statute passed April 14, ]900).

Johns Hopkins requires a degree in arts, literature, or science for admission. Harvard will require the same from all entering after September of this year. After 1901 the Western Reserve University, Cleveland, Ohio, will require the completion of the junior year in a recognized college, for admission to its medical department, and after 1903 the University of Chicago (see The Journal, April 21, 1900, p. 1014.) and the University of Minnesota will require the same. While too much can not be said in favor of the adoption of a collegiate education as a standard for admission by our leading universities, still, it would seem that it should be left to the judgment of the individual school, and that the completion of a high school course should be sufficient to require of all schools, but we should insist on that as a condition of admission and that the schools require four annual sessions of eight months each instead of six, and as all of our best schools now require it, let us demand it of all after 1903 .

Very truly yours,

William T. Slayton, M.D.

\section{Deaths and Dbituaries:}

Landon Carter Gray, M.D., died at his home in New York City, May 8, aged 50 years. He studied in Columbia and Heidelberg universities, and in 1873 took his degree in medicine at Bellevue Hospital Medical College: He began practice in New York City, but afterward moved to Brooklyn, where he was made professor of neurology at the Long Island College Hospital and visiting neurologist to St. Mary's Hospital. He was one of the founders of the New York Polyclinic and was its professor of nervous and mental diseases. $\mathrm{He}$ served as president of the American Neurological Association, the New York Neurological Society, and the Society of Medical Jurisprudence. He was also chairman of the executive committee of the American Congress of Physicians and Surgeons for three successive sessions, and the author of several medical works, among the most important of which is his text-book on nervous and mental diseases.

Tromas W. Gordon, M.D., Georgetown, Ohio, died April 21, aged 81 years. He was graduated from the Cleveland Medical College in 1846 ; from 1851 to 1860 he was professor of materia medica and therapeutics in the Cincinnati College of Medicine and Surgery, and during the Civil War was surgeon of the 97 th Ohio infantry. He was a member of the american Medical association.

Thomas Dobrins, M.D., Marysville, Cal., died May 5, of tuberculosis. He was born in Alabama in 1837, but lived in Missouri most of his early life. In 1855 , he was graduated from Brunswick College. He was an army surgeon during the Civil War, and at the close went to California, where he has since lived.

Carl Brumae, M.D., Detroit, Mich., died May 13, aged 83 years. He was born in Göttingen, Germany, and educated there in the public schools and university. In 1852 he came to America and located in Detroit, where he has since resided. He was a member of the Michigan State Medical Society and of the American Medical Assoctation.

RoBerT A. Ellis, M.D., died in Alaska, June 15, 1899 . He was about 100 miles from Cape Nome, and news of his death has just reached here. He was graduated from the Kentucky School of Medicine, in Lonisville, in the class of 1882, and for fifteen years had practiced in San Francisco. In 1898 he identified himself with a mining company and was looking after its interests when he was stricken with fever.

W. M. BuLlard, M.D., died recently in Fallbrook, Cal.
He was graduated from the Medical College of Indiana in 1876, and then located in Helena, Mont., where he remained until failing health necessitated a change of climate. DEATHS ABROAD.

Dr. Rafael Lavista, of Mexico, is dead. His name is associated with scientific progress in his country during the last half century; he was the official representative of Mexico at the last three international congresses, and the PanAmerican Congress at Washington. The Revista de Anatomia Pat. y Clin., of which he was editor, has suspended publication for the present.

We also note the deaths of Professor Bose, of Giessen, who had recently retired; A. Milne-Edwards and G. Planchow, of Paris.

\section{Zew Instruments.}

\section{An Improved Device for Rapid Hypodermoclysis. BY EDWIN M. HASBROUCK, M.D. WASHINGTON, D.C.}

In The Journal for March 3, page 520, Dr. Evan O'Neill Kane illustrates and describes a simple home-made device for rapid multiple infusion-consisting of a rubber bulb, glass medicine-dropper, rubber tubing and needles. The affair is a most useful one, but for other than absolute emergencies is too unstable in composition, both from the fact that after repeated sterilizations the rubber bulb is bound to deteriorate and eventually become useless-possibly just when most wanted-and that leakage is bound to occur at the points where the tubing is drawn through the bulb, possibly permitting the entrance of air at some stage of the operation.

Acting on the suggestion contained in Dr. Kane's apparatus, I have had made for me a simple little device that, like the eye-dropper, can be carried about in the pocket, or form part of every surgeon's outfit. It can be sterilized at a moment's

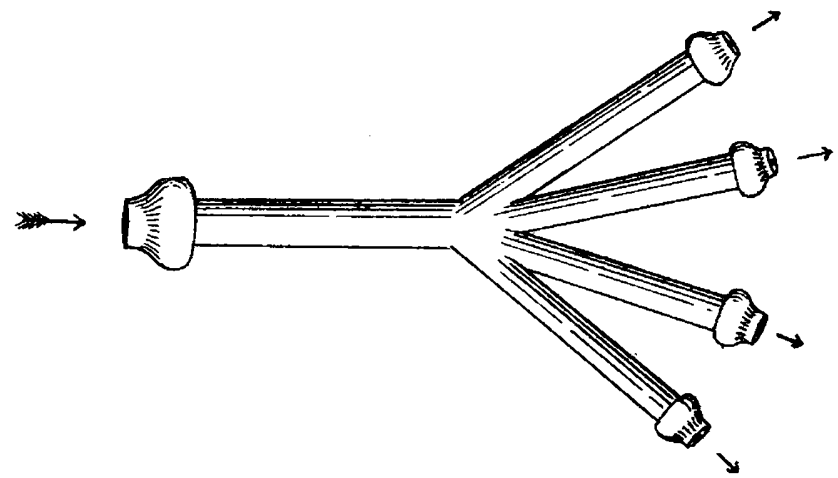

notice together with the needles and tubing, and it will last forever. It consists of a single metal tube provided with a bulbous end for holding the receiving tube from the fountain or supply tank. The lower end divides into four tubes, the ends of which are similarly provided for the feed tubes. The accompanying drawing shows the contrivance, exact size. For convenience and speed the four tubes with their needles can be Ieft permanently attached and dried after each usage-the whole apparatus to be kept in a little box in the instrument bag. While the improved apparatus is my own idea, the profession has to thank Dr. Kane for a most useful little contrivance. The instrument here illustrated was made for me by the W. J. McKee Company, of this eity.

2422 Fourteenth St., N. W.

\section{The Artificial Defecator and Irrigator.} BY ROBERT N. BARGER, M.D.

\section{HOPEDALE, ILL.}

We all recognize the importance of rest in the treatment and cure of disease, yet in hemorrhoids and rectal troubles we have never been able to apply this, for the reason that we must defecate daily and have never had a way for avoiding it, or of 